\title{
Albanien: Behov for EU imod korrupt system
}

Visar Rexhepi

I slutningen af 2009 fik Albanien formelt grønt lys til at søge om optagelse i $\mathrm{EU}$ og nåede dermed et foreløbigt højdepunkt i tilnærmelsesprocessen til EU. Det skyldes dog ikke deres politikeres fortræffeligheder

I 1999 lancerede EU den såkaldte stabiliserings- og associeringsproces (SAP) for det vestlige Balkan. Processen omfatter forhandling og indgåelse af Stabiliserings- og Associeringsaftaler. Den tilbyder landene i regionen væsentlige fordele, men stiller samtidig politiske og økonomiske betingelser, herunder regionalt samarbejde og godt naboskab. Landene skal også tilpasse deres politiske, økonomiske og institutionelle udvikling til grundlæggende værdier i EU - dvs. demokrati, respekt for menneskerettigheder og markedsøkonomi. Processen indebærer, at landene har udsigt til at blive medlem af EU, når de opfylder kravene til medlemskab - de såkaldte københavnerkriterier.

I 2006 indgik EU en Stabiliserings- og Associeringsaftale (SAA) med Albanien. Aftalen er første skridt i en proces, som senere kan føre til egentlige optagelsesforhandlinger, og i november 2009 fik Albanien formelt grønt lys til at søge om optagelse i EU.

\section{Stabilitet frem for alt}

SAP fremhæver stabilitet som den vigtigste strategi til at bekæmpe den usikkerhed og uro, som har kendetegnet Albanien de seneste 10 år, men hvor den del af processen, der drejer sig om politisk stabilisering af Albanien og udvikling af økonomien, er tænkt godt igennem, så er den mindre klar, når det gælder de efterfølgende skridt. Det blev dog først til et problem, da en vis udvi- 
delsestræthed begyndte at brede sig i EU-landene, og der fra flere sider blev rejst krav om et foreløbigt udvidelsesstop. Denne udvidelsestræthed kan være kortere eller længere afhængig af den interne udvikling i EU og situationen i medlemslandene. Men den indebærer et alvorligt problem for de lande, der aspirerer til at blive medlemmer.

Stabiliserings- og associeringsprocessen gav Albanien et håb om, at når den var tilendebragt, så ville EU fastsætte en dato for starten på egentlige medlemsforhandlinger, som det var sket for andre østeuropæiske lande. Nu hvor udsigten til EU-medlemskab er mere usikker, kan det blive svært at opretholde det hidtidige udviklingstempo. Nogle analytikere mener dog, at trods de nuværende udsigter, så er Albanien på ret kurs. En artikel i Economist antydede $\mathrm{fx}$, at den økonomiske udvikling i Albanien havde været så positiv, at udmeldinger fra EU om, at det var nødvendigt at sætte udvidelsestempoet ned, ikke bekymrede den albanske regering.

Denne analyse er kun delvis korrekt. Den albanske regering gør sig måske ikke de store bekymringer, $\mathrm{i}$ hvert tilfælde ikke i samme grad som regeringerne i Kroatien og Makedonien. Men denne ro skyldes ikke en stærk og bæredygtig udvikling, der er uafhængig af bistand fra EU, men snarere den albanske regerings overoptimistiske og forhastede forventning om, at Albanien uund- gåeligt vil starte drøftelserne om EU-medlemskab.

Dette standpunkt kan muligvis have en vis regulerende indflydelse, især fordi Vestbalkan i sidste instans nok bliver integreret i EU. Men tiden indtil det sker kan skade udviklingstempoet, lige som det skete i midten af 1990'erne.

De afsluttende forhandlinger om Stabiliserings- og Associeringsaftalen afslørede den albanske regerings politiske umodenhed og manglende evne til at tage fat på de forpligtelser, der følger af aftalen. Når det er sagt, så har regeringen gjort en vis samlet indsats for at leve op til forpligtelserne. Det er sket på trods af dens manglende erfaring, idet hele processen blev iværksat og udviklet af den tidligere regering, der var ved magten otte år i træk. Der var med andre ord en manglende kontinuitet, som måske ikke ville have været så stort et problem i andre lande, men som er et tilbagevendende problem i Albanien. Ethvert politisk parti, der vinder et parlamentsvalg, udskifter nemlig hele statsadministrationen med folk fra deres egen politiske lejr - og udtrykket 'hele statsadministrationen' skal i Albaniens tilfælde tages bogstaveligt.

\section{Krav fra EU}

De generelle principper for den politiske dialog mellem Albanien og EU fastlægger de hovedkrav, som danner grundlag for Albaniens in- 
denrigs- og udenrigspolitik. Disse hovedkrav er demokrati, lovmæssig forvaltning og respekt for principperne i såvel international lovgivning som fri markeds $ø$ konomi.

Ifølge disse principper må den albanske regering påtage sig løbende at forbedre samarbejdet med nabolandene, når det gælder den fri bevægelighed af personer, varer og tjenesteydelser. I Balkans tilfælde har EU understreget vigtigheden af et fælles regionalt samarbejde for at bekæmpe organiseret kriminalitet, menneskehandel, korruption, illegal immigration og hvidvaskning af penge.

Albanien og EU har i stigende grad koncentreret sig om lovmæssig forvaltning, god regeringsførelse samt bekæmpelse af terrorisme og organiseret kriminalitet. Forhandlingerne på disse områder afhænger af to faktorer: Den første drejer sig om samarbejde om personers bevægelighed og kræver lovgivning om visumordninger, asylpolitik og migration. På dette område har den albanske regering gjort betydelige fremskridt med hensyn til at vedtage love, men det er fortsat vanskeligt at føre den nye lovgivning ud i livet, især grænsekontrollen og visumordningerne.

Den anden vedrører bekæmpelse af terrorisme og organiseret kriminalitet og kræver lovgivning om retsligt samarbejde om kriminalsager. Specielt dette område er en stor udfordring for Albanien, der er transit- land for menneske- og narkosmugling, og både Albanien og EU har lagt vægt på at tackle problemet på regionalt plan. Der er et desperat behov for at fjerne Albanien fra kortet over organiseret kriminalitet, og regeringen tog i 2005 en række drastiske skridt og begrænsede blandt andet albanske motor- og sejlbådes sejlads i Det Ioniske Hav og Adriaterhavet. Selv om albanske handelsog turistorganisationer kritiserede foranstaltningerne, der stred mod deres interesser, har den albanske regering indtil videre fastholdt dem.

\section{Frihandelszone}

De tekniske aspekter af Stabiliserings- og Associeringsaftalen vedrører den fri bevægelighed af varer. Ifølge aftalen skal Albanien og EU oprette en frihandelszone. Det vil med andre ord sige, at Albanien må åbne sit marked for varer fra $\mathrm{EU}$ for at styrke den albanske økonomi, forbedre forbrugerbeskyttelsen og fremme erhvervslivets udvikling. Det har umiddelbart været hårdt for den albanske økonomi. De europæiske produkter er eftertragtede hos de lokale forbrugere og, trods hensigter om at forbedre den hjemlige produktion, skader de i de fleste tilfælde i virkeligheden de lokale producenter og bringer mange på konkursens rand.

Fremgangsmåden er ikke velgennemtænkt. Den har muligvis fungeret i andre østeuropæiske lande, 
men det er usandsynligt, at den skaber gode resultater i Albanien. Det skyldes, at det albanske bank-, låneog kreditgivningsystem er det mest dysfunktionelle i Europa. Det er overordentlig vanskeligt for erhvervslivet at få kredit på grundlag af produktivitet og resultater. Siden den ødelæggende pyramideskandale i 1997 er kreditorerne vendt tilbage til långivningens barndom, hvor kun varer og fast ejendom blev betragtet som sikkerhed for kredit.

Det vil tage tid, før den institutionelle tillid, der er en forudsætning for det finansielle system, kommer til at fungere igen. Indtil det sker, vil kun dé albanske virksomheder, der kan konkurrere med europæiske produkter, overleve, mens dé, der nok har potentialet, men som samtidig har behov for en hjælpende hånd i form af kreditter, måske ikke klarer den.

Processen vil ødelægge, hvad der måtte være tilbage af hjemlig produktion i Albanien, og i det forløb vil mange miste deres arbejde. En løsning kunne være udenlandske investeringer, men med Albaniens elendige infrastruktur, især elektricitet og veje, er det usandsynligt, at udenlandske investorer vælger Albanien som deres favoritdestination. I hvert tilfælde ikke i løbet af de næste fem år. Det ville have været en fremragende ide, hvis EU havde valgt at gå ind og fylde hullerne $i$ denne proces med mikrolån i stedet at yde finansiel hjælp til regeringen til at stabilisere den finansielle sektor, da det højst sandsynligt ikke kan ske udelukkende ved regeringens indsats.

\section{Skuffede forventninger}

Trods indledende optimisme med hensyn til de første fri valg efter det kommunistiske regimes fald er det billede, der har tegnet sig af den albanske politiske elite, mindre end positivt. Det har tilsyneladende været vanskeligere end forventet at overkomme den kommunistiske arv.

Det Demokratiske Parti vandt valgene både i 1992 og i 1996, men begge valg gav anledning til voldsepisoder. Det Demokratiske Parti blev tvunget fra magten efter kollapset af pyramidespillet, som partiet i vælgernes øjne - nok ikke uden grund - var tæt forbundet med.

Valget i 1997 blev vundet af Socialistpartiet, der beholdt magten efter valget i 2001. Dette valg blev afholdt under international overvågning, men førte ikke desto mindre også til voldsepisoder. I marts 1997 blev der dannet en koalitionsregering, Den Nationale Forsoningsregering, men efter et voldeligt oprør blev der i juni 1997 dannet en ny koalitionsregering, stadig under socialistisk ledelse.

I det første årti efter kommunismens sammenbrud lykkedes det ikke den politiske elite på nogen af siderne at leve op til internationale normer for et liberalt demokrati. 
Misbruget af politisk magt som følge af stigende korruption og krænkelser af menneskerettigheder førte i retning af etpartistyre og en stadig mere forgiftet politisk atmosfære. Den politiske diskurs om et hvilket som helst emne udartede sig til, at de to hovedmodstandere, Demokraterne og Socialisterne, rakkede ned på hinanden.

Lederne af begge partier var diktatoriske både i omgangen med hinanden og med deres egne partier. Socialiserede i kommunisttiden var lederne af både Demokraterne og Socialisterne ude af stand til at tilpasse sig de ny vilkår, og i stedet forfaldt de til spil for galleriet og autoritært styre. Det havde en negativ indflydelse på hastigheden af reformprocessen og bidrog til yderligere at underminere landets stabilitet.

Det er den almindelige opfattelse, at der blev svindlet med valget $\mathrm{i}$ 1996, og der er beviser for, at nogle vælgere stemte flere gange, og at ytringsfriheden blev indskrænket. Det Demokratiske Parti undlod at tage fat på spørgsmålet om korruption, og det fik mange albanere til at miste tilliden til politi og domstole pga. det udbredte kendskab til forbindelsen mellem bander, politi og regeringsmedlemmer. Politiets krænkelser af menneskerettighederne bidrog yderligere til vælgerkorpsets mistillid og fornemmelse af, at nepotisme og klientelisme havde infiltreret regeringsstrukturerne.

Begge partier har også forsøgt at kontrollere medierne i stedet for at fremme udviklingen af frie og åbne medier. Fatos Nanos socialistiske regering var ekspert $i$ at chikanere og censurere medierne, og selv om Sali Berishas demokratiske regering ikke åbenlyst har angrebet medierne som Nano gjorde, så lykkedes det heller ikke den at gennemføre en medielov, der garanterede medierne uafhængighed. Regeringen har desuden været langsom til at udstede permanente sendetilladelser, så de elektroniske medier er havnet i en sårbar situation, hvor det er svært at skaffe de nødvendige midler, fordi sendetilladelserne kun er midlertidige. Det har fremmet en barsk selvcensur.

Endelig blev den tætte forbindelse i vælgerkorpsets bevidsthed mellem den demokratiske regering og de kollapsede pyramidespil i foråret 1997 opmuntret af Socialisterne, der på den måde gav næring til retsstatens mulige sammenbrud, efterhånden som våbenlagre blev plyndret, og bevæbnede bander tog kontrol med flere områder i syd. I stedet for at støtte retsstaten greb oppositionen chancen til at fremme sine egne mål. Da staten brød sammen i foråret 1997, var det derfor måske ikke så overraskende, at der i dette politiske tomrum blev lagt stigende vægt på Kanuns autoritet (Kanun er en sædvaneret, der stammer fra Nordalbanien. Red.) Det underminerede kvinders stilling yderligere, øgede antallet af blodfejder og styr- 
kede bandernes magt. Med den sammenbrudte økonomi og tabet af folks opsparinger blev migration en vigtig strategi for de familier, der kunne finde midler til at sende et familiemedlem udenlands.

\section{Fortsat mudderkastning}

Socialistpartiet vandt som nævnt valget i 2001, men trods dets tidligere kritik af Demokraterne, syntes partiet ikke at gøre meget for at få styr på de problemer, der havde plaget dets forgængere. Korruptionen fortsatte uhindret, og grænserne forblev svage, hvilket fik Europarådet og andre europæiske institutioner til at kritisere regeringen. Socialistpartiets leder, Fatos Nano, der selv var tidligere kommunist, styrede sit parti på en måde, der mest mindede om kommunisttiden, og eliminerede al væsentlig opposition inden for partiet. Bl.a. blev de to tidligere premierministre, Ilir Meta og Pandeli Majko, tvunget til at trække sig tilbage.

Det er heller ikke lykkedes den siddende regeringsleder Sali Berisha, der er leder af det Demokratiske Parti, at skjule sin kommunistiske ballast. Til trods for at han i vælgernes bevidsthed forbindes med modstand mod socialisterne, forbliver han tæt forbundet med den kommunistiske mentalitet.

Også under Socialistpartiets nuværende leder, Edi Rama, er der intern uro i partiet. Rama led nederlag ved parlamentsvalget i 2009, og den eneste måde han har kunnet forblive ved magten i Socialistpartiet var - og er - ved at forkaste valgresultatet og erklære det for manipuleret. På den måde har han lettet presset på sig selv for at træde tilbage.

I opposition er begge partier grebet til boykot af valgresultater, når de ikke har fået deres vilje, og således gjort det muligt for det regerende parti at opføre sig mere autokratisk. Den situation blev overvundet i 2002, da det lykkedes Den Europæiske Union at forhandle en fælles aftale mellem de to store partier. I 2003 var de imidlertid vendt tilbage til de gamle vaner, selv om brugen af boykot er blevet mindre.

Det er et stort problem, at enhver ny regering har været tilbøjelig til helt at udskifte politiets styrende organer. EU var uhyre kritisk over for Det Demokratiske Parti og Socialistpartiet i tiåret efter kommunismens fald. Perioden beskrives som én, hvor "konfrontation og konflikt var den politiske norm, og fjendskab forhindrede en konstruktiv politisk proces". Dette fjendskab mellem de to store partier får også skylden for at have fjernet opmærksomheden fra kampen for at få den udbredte kriminalitet under kontrol, eftersom områder som Lazarat i syd og Bajram i nord stadig kontrolleres delvis af bander og klanledere. Endelig er der en tendens til, at både partier og vælgere forveksler det parti der har magten, med staten, hvilket 
fremgår af partiernes vane med at udskifte hele personalet med deres egne 'kumpaner', når de kommer til magten.

\section{Nepotisme og korruption}

Den aktuelle situation i albansk politik er udtryk for den politiske elites negative holdning til både EU og egen befolkning. De nuværende politikere har monopolitiseret albansk politik, og vi har nu et topartisystem, der lægger op til, at de i al evighed kan skiftes til at have magten. Socialister og Demokrater har skabt en bipolær situation i albansk politik, hvor de to partier er fælles om interessen i at sikre sig ejerskab over de største virksomheder i landet.

Den privatiseringsproces, der har fundet sted de seneste 20 år, har bortset fra Ruslands været den mest korrupte i verden. Som eksempel kan nævnes privatiseringen af Hotel Tirana: Det blev købt af forretningsfolk med forbindelser til Demokraterne og Socialisterne, og hvor den gennemsnitlige kvadratmeterpris for ejendomme i Tiranas centrum er mellem 2.500 og $4.000 \mathrm{USD}$, så blev Hotel Tirana solgt for 76 USD per kvadratmeter. Salget af bryggeriet Birra Tirana er en anden skandale, som aldrig er blevet omtalt i medierne.

Da Det Demokratiske Parti vandt valget i 2005 blev det skarp kritiseret af Top Channel (en af de største tvstationer i Albanien. Red.), som kort efter blev offer for regeringsbureaukratiet, da den blev idømt en gigantisk bøde på 12 mio. USD, der kunne tvinge kanalen til at lukke. Top Channel og andre medier protesterede over bøden, men efter tre måneder var der ikke længere nogen, der talte om den. Men et er sikkert: Top Channel er ikke længere så kritisk, som den plejede at være, og dermed er et af de sidste kritiske frie medier forstummet.

Albansk politik har siden 1990 været dikteret - nogle kalder det styret - af den samme politiske klasse. Socialister og Demokrater har været gode til at samarbejde, når det har drejet sig om at skabe et topartisystem i Albanien - og det er lykkedes. Desværre for Albanien har erfaringerne med flerpartisystem heller ikke været gode, idet de små partier som tungen på vægtskålen fik alt for megen magt, som de uhindret misbrugte.

Albanien har lidt under sine politikere lige siden kommunismens fald. Uanset hvordan man ser på det, er det den albanske middel- og underklasse, der betaler prisen for at være stillet uden for den europæiske familie. Og mens albanske borgere på mange områder har forbedret deres adfærd betydeligt, så har de albanske politikere indladt sig på en destruktiv politik. Det er vigtigt at forstå, at de største tilbageslag for Albanien i de seneste år skyldes de politikere, som vi selv har 'valgt'. 


\section{Ny strategi}

EU befinder sig i en situation, som unionen ikke har oplevet før. Den prøver på alle mulige måder at skubbe Albanien mod EU, men strategien for de betingelser, der skal være opfyldt, giver blot vores politikere endnu mere tid til at blive integreret.

Men jeg tror, at EU efterhånden har gennemskuet de albanske politikeres attitude og nu vil anlægge en ny strategi, som hedder: Albanien bliver medlem af EU inden for de næste fire år, uanset den politik eller de reformer der bliver gennemført. EU håber, at i det øjeblik det har Albanien under sin paraply, kan det bedre hjælpe det til at respektere de love, der har eksisteret i mange år. Hvis EU i sidste instans lader det være op til albanske politikere, hvornår Albanien bliver medlem, vil det sandsynligvis ikke ske de første syv til 10 år.

Albanske borgere er blevet stadig mere skeptiske over for, om der overhovedet er mulighed for at få gennemført god regeringsførelse i landet. Mange politikere i Albanien har været på den politiske scene $\mathrm{i}$ mere end 20 år, og ingen af dem har trukket sig tilbage, selv om de har det fulde ansvar for at trække Albanien ind i et feudalt system, som kun feudalherren - politikeren har fordel af.

Ikke desto mindre er det min opfattelse, at Albanien, trods indenrigspolitikken, i nær fremtid bliver medlem af EU, og når først EU får noget at sige, vil Albaniens politiske system undergå en mindre revolution, og den albanske befolknings potentiale endelig for alvor komme i spil.

Visar Rexhepi er født i Kosovo i 1984, men flyttede til Albanien som tiårig. Han er uddannet $i$ Storbritannien, og blev efter sin kandidateksamen ansat ved UFO University $i$ Tirana. Han bor og arbejder nu $i$ USA.

Oversat fra engelsk af Brita $V$. Andersen. 